\title{
ESTABLISHMENT OF ENTREPRENEURIAL CHARACTER SANTRI BASED ON HUMAN RESOURCES MANAGEMENT
}

\author{
Aulia Zahra Husnil Kamala ${ }^{1}$, Silviana Pebruary ${ }^{2 *}$ \\ ${ }^{1,2}$ Universitas Islam Nahdlatul Ulama Jepara, Indonesia \\ e-mails: ${ }^{1} a z 8156055 @ g m a i l . c o m ;{ }^{2}$ silvy@unisnu.ac.id
}

Received June 10, 2021; accepted July 22, 2021; published July 28, 2021.

\begin{abstract}
Objective: This research analysis about management human resources for santri Pondok Pesantren Darul Falah Amtsilati to manage academic and business personality. Research Design \& Methods: This research uses qualitative research methods with case study approach. The data source in this study is primary data by conducting in-depth interviews to the manager (academic \& business) and santri Pondok Pesantren Darul Falah Amtsilati. And observations were made to observe directly about the state of Darul Falah Amtsilati boarding school. Data analysis techniques use source triangulation. Findings: The results of this study showed that in the formation of the character of boarding schools Darul Falah Amtsilati using methods of precision, planting discipline, habituation, creating a conducive atmosphere, as well as integration and internalization. From the formation of the entrepreneurial character has been done based on the character of Islamic human resource. Where shiddiq is taught with honesty, trust by emphasizing responsibility, tabligh conveys correctly, and fathonah is realized by the selection of santri based on criteria. Implications \& Recommendations: The implication of the results of this study is that the pesantren has used Islamic resource principles in the recruitment and learning process but needs to be improved or perfected in the implementation of learning by creating special classes for business character building. The aim is to help develop the quality of productive pesantren business managers. Contribution \& Value Added: The contribution of the results of this study is to provide input to pesantren in improving the quality of prospective Islamic resources who will become managers of productive business activities of pesantren.
\end{abstract}

Keywords: pesantren management; character building; Islamic human resource.

JEL codes: I2, M2

Article type: research paper

\section{INTRODUCTION}

Indonesia is a country with a Muslim majority and there are several non-formal educational institutions based on religious education, one of which is Islamic boarding schools. Pesantren is a traditional education where students study under the guidance of teachers or often known as Kiai, the students also live together in a dormitory for students to stay. In the pesantren complex, students are provided with a mosque for worship, space for study, and other religious activities. This complex is usually surrounded by a wall to be able to monitor the entry and exit of the students in accordance with applicable regulations (Syarofi, 2018). Pesantren as an institution that lives in the midst of society, has a very important role, both related to religious issues (moral force) and those related to social society (Nadzir, 2015). There are various expectations and predicates attached to Islamic boarding schools. With three main functions, namely: 1) as a center for cadre of religious thinkers (centre of excellence); 2) as an institution that prints human resources (human resources); and 3) as a 
power institution to empower the community (agent of development) (Halim et al., 2005; Wagola, 2018). Meanwhile, the objectives to be achieved by Islamic boarding schools in producing community empowerment cadres are: (1) developing entrepreneurial character among students and the community; (2) developing centers and business units that are highly competitive; (3) establishing a Microeconomic Institution based on Islamic values; and (4) developing economic and funding networks in pesantren (Rimbawan, 2012).

In economic development, mastery of this economic capability concerns individual performance where the form of competence of the individual can be increased through the learning process or directly involved in the field, such as the competence to manage the economy (Damihartini \& Jahi, 2005; Hanani, 2005; Rimbawan, 2012). The ability regarding the knowledge and skills of economic managers here that need to be improved involves several aspects: (1) human resources; (2) entrepreneurship/entrepreneurship; (3) administration and management (organization); and (4) agricultural techniques. Therefore entrepreneurship education is very necessary to be held. In addition to providing skills, entrepreneurship education can also be a means to instill entrepreneurial values, then be able to foster an entrepreneurial spirit. In national education, one of the challenges is how to give birth to human entrepreneurs from educational institutions, both formal and non-formal education (Tilaar, 2012).

Pesantren is a non formal educational institution that produces someone who has competence in terms of religiosity and social skills that is ready to compromise in the outside world. Associated with the challenge of giving birth to entrepreneurial humans, in this case a student must have an entrepreneurial character to be able to create a business opportunity. While the notion of entrepreneurship itself is that entrepreneurship is someone who has a great personality, is creative, productive, able to carry out planning activities, starting from his own ideas, then developing using the power of others and also always adhering to the values of discipline and high honesty (Alma, 2000; Saepudin, 2005). The character here refers to a series of knowledge (cognitivies), attitudes, and motivations, behaviors, and skills (Falah, 2018). According to Hidayatullah \& Rohmadi (2010) and Falah (2018) formulated character education methods into five kinds, namely: a) civility in education; b) method of planting discipline; c) habituation methods; d) create a conducive atmosphere; and e) integration and internalization.

In this case pesantren is one of the institutions that can support giving birth to human beings who have a great person, creative and honest as a provision to become an Islamic entrepreneur. The number of Islamic boarding schools in Indonesia so far this year, according to the Indonesian Ministry of Religion's database of Islamic boarding schools, is 26,974 Islamic boarding schools, while for Central Java alone there are 3,787 Islamic boarding schools. Jepara is one of the cities that has the motto "Continue to Work Hard to Build the Region" and there are 176 pesantren, this shows that pesantren in Jepara has the potential to make the city with productive pesantren as a support from the improvement of the regional economy because pesantren synergize with the motto of Jepara city. Pesantren is a non-formal educational institution that is able to form the character of human resources to meet the needs of professional workers in Islamic entrepreneurship. One example Darul Falah Amtsilati Islamic Boarding School is a boarding school located in Jepara Regency.

Pesantren is famous for learning the yellow book (Kitab Kuning in Bahasa), but on the other hand it turns out that the pesantren has several business fields, namely printing, business cooperatives, inns and restaurants, mineral water companies. The business owned by the pesantren involves its students in managing the business. Of the many business units owned by Darul Falah Amtsilati boarding school, it is classified as a productive pesantren, and able to manage human resources in pesantren to create a spirit of literature. This makes researchers want to know if this pesantren uses human resource management in the management of pesantren and provide learning to the students, because the pesantren is actually a boarding school to study the yellow book.

Therefore, researchers conducted observations at Pondok Pesantren Amtsilati to find out and analyze how the manager of the pesantren in managing and forming students on the character of Islamic entrepreneurs as well as a positive economic life with a base of human resource management in the 
formation of character cadres of pesantren business managers. Thus from the results of this study is expected to be a reference by other pesantren to improve the quality, become productive pesantren and produce students who have the soul of Islamic enterprise.

\section{LITERATURE REVIEW}

Character is the value of human behavior related to God Almighty, environment, self, fellow human beings, and nationalities formed in thoughts, attitudes, feelings, words, and deeds based on religious norms, cultures, laws, manners, and customs (Samani \& Hariyanto, 2011; Subekti, 2018; Syafe'i, 2017). For the term character itself is considered the same hamper as personality, in this case personality as a trait, or characteristic, or style, or characteristic of one's self derived from something received from the environment (Koesoema, 2010). But what distinguishes here is that the character is more on one's mental state in responding to the situation with a good moral path. Then Lickona (1996) and Falah (2018) suggests that the character so conceived has three interrelated parts: moral knowing, moral feeling, and moral behaviour. So that the meaning of this noble character includes knowledge about goodness (moral knowing) then gives rise to commitment or intention to goodness (moral feeling) and finally good (moral behaviour). The character here refers to a series of knowledge (cognitivies), attitudes, and motivations (motivations), behaviors (behaviour), and skills (skills). According to Tian (2021), personality characteristics can be measured by extroversion, conscientiousness, understanding, emotional stability, and openness.

In character formation the most important thing is the mind because in the mind, there are all programs that are organized based on his life experience. Furthermore, this program forms a belief system which is ultimately able to form a mindset that can influence his behavior. In other words, character building can be termed as the formation of a person into a bodybuilder who requires "exercise of moral muscles" continuously in order to be strong and strong (Muslich, 2011; Sahlan, 2013; Syafe'i, 2017). So that from the above understanding can be accommodated that the character of a human being can be changed and developed. Related to that, Erich Form suggests that basically the character should be sought in the pattern of one's relationship with the environment, objects or humans (Falah, 2018). Efforts in character building are through education. Character education is an effort with the aim of educating children to be wiser in making decisions and practicing them in daily life. So that they can make a positive contribution to the environment. By being given education and entrepreneurial examples, students will be easier to form self-reliance in entrepreneurship. According to Aryani (2019), the social influence of entrepreneurship shows that the culture of dependency, pilot culture, traditional culture and religion, culture of success and failure, social security network will make a person steadfast and persistent, have the ability of self-control, confidence and flexibility in doing business.

In Indonesia Heritage Foundation (IHF) character education takes precedence over the development of basic characters that become the basis in the behavior of each individual. The nine characters are: 1) love to god and the universe and its contents, 2) responsibility, discipline and also self-reliance, 3) honesty/ trust, 4) respect and courtesy, 5) compassion, care, and cooperation, 6) confident, creative, hardworking and unyielding, 7) justice and leadership, 8) kind, humble, and 9) tolerance, peace and unity. These nine basic characters that are the goal in character education (IHF, 2000b). Character formation with processes such as discipleship, habituation or culture in the environment of students in educational institutions, families and communities as well as the mass media environment in character education is very important (Falah, 2018). Hidayatullah \& Rohmadi (2010) and Falah (2018) formulating character education methods into five kinds of:

1. civility in education, this method of an educator is a good example in the view of learners, which in the act of horns and manners both from speech and deeds by itself will be emulated.

2. Method of planting discipline, method of planting discipline is done in applying the character of entrepreneurial independence.

3. Habituation method, if the environment teaches doing good in the growth of children, then the child is expected to be accustomed to doing good. On the contrary, if the environment teaches to 
commit crimes, violence in the growth of children, then it will grow into a new perpetrator of violence and evil.

4. Create a conducive atmosphere, by managing the boarding school environment as conducively as possible, so that in the future it will support the programs of planting entrepreneurial self-reliance character. Between one business unit and another business unit, it is regulated as efficiently as possible.

5. Integration and internalization, in character education the process of internalizing values into the hearts of students is needed agat can grow from within. The values of the character such as independence, trust, respect for people, honesty, patient discipline, etc. and internalized in all activities of learners.

Regarding the character of entrepreneurial independence, the integration is by directly parachuting students in the business activities of boarding schools, then by making the rules of student (santri in Bahasa) not to receive/ ask from/ to parents, and by meeting the needs of students during their stay in boarding schools. Thus students not only study religion, but also have the ability to independently be entrepreneurial. Priyantom (2009); Reginald \& Mawardi (2014); and Nasir (2019) say that entrepreneurship is everything that is in one's soul, be it society and organization that can produce various activities (social, political, educational), business and business. In entrepreneurship there is very wide coverage both of individual entrepreneurship, industrial entrepreneurship and social entrepreneurship. Soetojo (2013) and Irawa (2019) explain that Entrepreneurship is a spirit, attitude, behavior and ability possessed by a person in running a business with various efforts to provide good service and or gain greater profit. Soetojo (2013) entrepreneurship there are several basic principles that need to be cultivated by a leader, that is:

1. strong ability to work with an independent spirit (especially in the field of economics).

2. Ability to solve problems and also make decisions including courage in taking a risk.

3. Ability to think and act creatively and also innovatively.

4. Willingness and ability to work in togetherness based on sound business ethics.

While self-reliance according to Barnadib (1987); Syafaruddin (2012); and Misjaya et al. (2019) that is a person's circumstances to determine oneself where it is seen in the form of an action or behavior of a person and can be assessed, including the ability to take initiative, able to overcome obstacles/ problems, have confidence, and can do anything on their own without the need for the help of others.

Entrepreneurship in boarding school is encouraged by the students who manage it and are able to contribute to the santri of economic independence which means the ability of students to determine themselves about the economy in the future by improving the life skills owned by students. With these life skills, students feel ready when entering the world of work later. Santri has economic potential that needs to be explored, so it must be instilled and also developed, then fostered and also trained in order to form the soul of economic independence in the santri. According to Vamvaka et al. (2020), instrumental and affective attitudes are perceived as a control factor of entrepreneurial intentions, this control factor is a commitment to entrepreneurship. According to Saepudin (2005) a student can be said to be independent if it meets the indicators of self-reliance as follows:

1. the cognitive aspect is the ability to know, and understand yourself and his environment; this aspect can be done with the learning process through the development of insights. For the application to the students, namely by providing material about entrepreneurship.

2. Affective aspects are courage, self-confidence, optimism, responsibility, patience, and sincerity; in this aspect to build it by giving learning that emphasizes the emotional aspect, with muhasabah, prayer, ritual worship, reverence, etc.

3. Conative aspect, attitude can accept yourself as well as environment positively and dynamically, able to control and direct yourself in accordance with the decisions taken, and have a strong determination not to be a burden of others).

4. Psychomotor aspects (ability to form oneself (self-actualization) optimally in accordance with the potentials, interests, and abilities possessed by the ikhtiar experts); therefore, it is usually given learning in the form of life skills, simulations, business exercises, internships, etc. 
According to Muttaqin (2016), the greater the motivation of a student, the greater the willingness to achieve the desired goal, so that from here resulting in the self-behavior of a student will be greater. The greater the independence of the students, the more active the students will be in seeking information, the more confident, able to solve their own problems without the help of others, like to work hard, sports to compete healthily, have the need to excel. Kind of self-reliant person can be said to be independent who does have a view of life as a whole, more realistic and objective to himself. So it can be concluded that self-reliance is basically born from the realization of thought activities, dhikr, and endeavors based on the following entrepreneurial indicators: there is a strong determination not to be a burden, hard work, responsible, courage, confident, able to understand yourself, able to control themselves, have an optimistic attitude, patient, tawaqal and sincere, self-actualization, and expert endeavors. Students who have clarity of life goals will give birth to self-reliance. While the clarity of life's own goals is due to a clear vision of education. A person's independence depends on how he or she organizes himself or herself in attitude or self-management. In a management there are six elements in it, namely: man, money, method, materials, machines and market. Human element developed into a field of management science called Human Resource Management (HRM) (Hasibuan, 2005; Norvadewi, 2018). Meanwhile, human resources are people in an organization where contributing thoughts also do various types of work to achieve the goals of the organization (Sukirno et al., 2011).

One of the areas of general management is human resource management, where general management as a process covers aspects of planning, organizing, implementation and control (Rivai, 2009). Therefore, human resource management is defined as an appropriate planning in organizing a goal sustainably through the potentials possessed by humans to achieve also balance a goal, either material or abstract/ immaterial (Al Hasan \& Maulana, 2016; Norvadewi, 2018). Jusmaliani (2014), humans for Islam is homo-Islamicus refers to As-Sajdah: 9,

"Then he perfected it, and breathed into it his soul, and made for you hearing and sight and hearts, but you were grateful."

The blowing of the spirit that is meant is the noble nature of God is also blown on man. So that by making man as a homo-Islamicus creature. In human resource management it is intended that human resource management must be able to accommodate the purpose of human life that always presents God in every activity, action, and in decisions related to work and work. According to Jusmaliani (2014), carrying out economic activities requires human resources that have an Islamic character so that there are no irregularities in practice. Reference in managing human resources is from the character of the Prophet, because these qualities can also be used as a reference to foster employees to achieve the welfare of the world and the hereafter. It can also be used in the process of procurement of labor, can be used in training, can be used as a reference for management, in conclusion the character of the messenger of Allah is an ideal attitude that must be owned by human resources of the company. Because in managing human resources, people here become the driving resources of a production process in which in this case must have characteristics and noble qualities exemplified by the Prophet (s) as the basis in every economic activity and as a basic human attitude (fundamental human ethics) who are able to support a success (Antonio, 2011). This is in line with the opinion of Fauzia \& Riyadi (2014) that the Messenger of Allah is an example for the formation of good character for human resources. These qualities are (Jusmaliani, 2014):

1. Shiddiq (true and honest). Honest workers will generate trust that becomes the main capital in every business.

2. Amanah (trusted, responsibility). Work must be mandated in accordance with the provisions of the. In living life, a Muslim must carry out all the commandments of Allah and abandon all His prohibitions (Hafidhuddin \& Tanjung, 2003).

3. Fathonah (smart). In this case the nature of Fathonah is intended that the selected workers must be smart and smart because they are required to always adapt to new technologies, new ways of working and so on. Intelligence makes workers quickly learn to absorb new things needed in competition. 
4. Tabligh (communicative). People who have the nature of tabligh will convey something correctly (weighted) and with the right speech will also not reduce or add to a word to be conveyed.

Of the four attributes above that God has given in the Prophet is basically a key success factor in managing a business. Those who manage a business with this nature, then the business will get a dip in high moral values (Syakir Sula \& Kertajaya, 2006). According to Wagola (2018), the ideal concept of entrepreneurship education in Pondok Pesantren Ulumul Qur'an is the concept of Islamic entrepreneurship education, with the empowerment of students through devotion, and making business units as contributions to pesantren, students and the community to build the independence of pesantren and santri. According to Rina et al. (2018), that entrepreneurial learning conducted based on the project can form the entrepreneurial character of students which includes: creative, independent, honest, and disciplined.

According to Marwansyah (2010), human resource management is the utilization of human resources in the organization, which is carried out through the functions of human resource planning, recruitment and selection, human resource development, career planning and development, compensation and welfare and work safety and industrial relations. Recruitment process of students must comply with good criteria. As is the case in the application of Islamic human resource management based on the ethical values of belief and motivation (Khan, 2016). In the Islamic human resource management, all the processes of recruitment, training, and compensation are carried out on the principle of Islam (Azmi, 2015; Fesharaki \& Sehhat, 2018). Educational institutions are expected to empower and optimize the use of resources to survive. In pesantren using ethical learning related to Islamic concepts, Islam has universal teaching values that suit human needs. The perfection of Islamic teachings is seen in the harmony of the values of teachings with human nature, which means that these teachings are in accordance with human growth (Handayani, 2019). Sharia guidelines and the goal is to achieve Sharia Maqasid (sharia goals) preservation of religion, life, intellectual, descent and property. This is directly related to the three mentioning components of Islamic jurisprudence relating to faith, morality and important human actions. In general, 'maslahah 'ammah' for the public benefit includes the five Maqasid Sharia mentions and here the next section onwards discusses in detail about how Islamic teachings encourage maslahah 'ammah and at the same time can achieve Maqasid Sharia (Othman, 2017).

Study of Irawan (2019) shows that Nurul Hakim Boarding School is an institution that is totally ironfat. The method of development of entrepreneurial independence of santri-based pesantren conducted is the Board of students as the driver of the program, there are demands to encourage the development of entrepreneurial independence of santri-based pesantren, the development of entrepreneurial independence of students, namely agribusiness entrepreneurship education, sewing, welding and automotive as well as sharia financial services. According to Nasir (2019) empowerment of students in the empowerment stage: 1) planning the networking of new ideas or ideas for business improvement efforts; 2) strict selection based on achievements for the placement of authority; 3) briefing before work ends; 4) provide encouragement of work spirit; 5) motivation as motivation for better work; 6) empowerment through leadership; 7) employee empowerment; 8) innovating; and 9) the leadership conducts supervision.

Nasrullah et al. (2018) in its discussion stated that almost all pesantren in Pekalongan have business units. Business units are mostly engaged in trading. The governance of the business unit is done simply. But pesantren involve santri in business management. Human character will be formed by itself through environment. If the environment is good it will have a positive impact. And vice versa. Febriyanti et al. (2018) in the research that has been done explains that the character of entrepreneurship as the formation of the character of students is carried out in non-formal education, namely through some form of orientation of training programs, physical forms, spiritual transfer of knowledge, activities in the form of training and skills activities that strengthen the independence of students.

From some previous research, it can be drawn hypotheses that human resource management used for reference in the formation of Islamic entrepreneurial character is shiddiq (true and honest), trust 
(honest/ trustworthy, responsible), fathonah (smart), tabligh (communicative). Of the four elements can be explained in various circumstances such as professional, trustworthy, creative, have work and spiritual motivation and those elements are intertex in achieving a goal. In the learning process it is necessary to emphasize that these elements need to be done and practiced in entrepreneurship, as pesantren evacuees are obliged to give examples to the students. Possible learning methods used for students are civility in education, discipline planting methods, habituation methods, so as to create cognitive attitudes, affective attitudes, conative attitudes, and psychomotor attitudes. It can realize the Islamic entrepreneurial spirit of the students.

\section{METHODS}

The type of research conducted by researchers is a qualitative type of research using a case study approach to uncover how pesantren managers form the character of entrepreneurial students in Darul Falah Amtsilati boarding schools based on human resources. So the researchers conducted observations and in-depth interviews at Darul Falah Amtsilati boarding school in Jepara Regency. The selection of this location is based on the background of productive pesantren in the Jepara area. This study uses a qualitative approach to recognize the phenomenon that occurs. Informants in this study include academic managers, business managers, and students from the boarding school. This research is expected to evaluate and develop the pesantren economy and formulate strategies for the formation of the soul of student independence through the development of pesantren economy. In testing the validity of the data researchers use the method of triangulation analysis of the source, by giving the same questions to all informants then reducing the data of interview results.

\section{FINDING}

In this study there were nine respondents who became informants and will explain the various questions presented by researchers. Respondents from this researcher are 9 (nine) people where one person from the academic manager (informant 1), two people from the business manager (informants 2 and 3), and six people from the boarding school students Darul Falah Amtsilati Jepara (informants 4, $5,6,7,8$, and 9). Field observations concluded that there were several santri activities conducted in Darul Falah Amtsilati boarding school, some went to school, some recited and some also participated in running the business.

Basically the purpose of santri is the same as studying religious science more deeply. However, the reason for students to enter the boarding school must be different, whether it is from self-desire or from the demands of parents. So the learning was initially different. But over time each student must experience a change of different thoughts that were not at home either from his learning that was not used to much memorization, then the yellow books that are difficult to understand become more understandable and even become at home in pesantren. This can also be due to the friendship that may be equally from newcomers, then both struggle in deepening the science of religion in a boarding school, where in his life is very demanded by the rules then learn to share with others, adapt, not only think of yourself but also others so that the life of this pesantren is not stand alone. The interaction 24 hours every day with friends also creates their own atmosphere that is able to eliminate the feeling that was initially the reason not to feel at home. And in fact life is called pesantren tested because life is far from parents, then adapt to the new rules that must be done and there is its own accountability. Then from the uniqueness of learning and so forth. Seen also in the boarding school Darul Falah Amtsilati there are several businesses run and seen also who run is his own santri. The vision of pesantren is "Realizing Pondok Pesantren Amtsilati as one of the centers of Education and Training that is able to produce students with morality karimah and high-faith, thick faith, Mastering science and technology to get the success of the world and the hereafter and Ridlo Allah SWT". The Mission of Pondok Pesantren Amtsilati is as follows:

1. The creation of students as a Muslim who mastered the science of religion competent in accordance with the Program Amtsilati and post-Amtsilati programs that include the science of tools (Nahwu and Shorof), Fiqh, Tafsir, Hadith, Sufism and Language. 
2. The creation of students who master science and technology and are competent in their fields, in accordance with the program organized by Amtsilati, namely integrated Islamic Junior High School and Islamic Vocational High School.

3. The creation of cooperation with relevant agencies and the industrial business world.

4. The creation of students who are sensitive to social situations and think to find a settlement of social problems.

5. The creation of students who have an independent and entrepreneurial spirit and berakhlakul karimah.

In addition to focusing on learning to read the yellow book quickly, Darul Falah Amtsilati boarding school can manage a considerable business. Although teaching and learning activities are based on the yellow book, boarding schools also insert activities for the formation of entrepreneurial character. Although the formation of entrepreneurial character in Darul Falah Amtsilati boarding school is not a target in learning achievements from boarding schools. But entrepreneurship is really used to facilitate students in the formation of entrepreneurial character. Where for the supply is done through KBM and practice in several businesses managed pesantren, among others: 1) printing; 2) RM Amtsilati Hotel; 3) Arwana Café; 4) Amtsilati bottled water; 5) building shop; 6) mini market.

Based on the results of interviews with informants, each question item regarding the character formation of human resource management students is shown in Table 1, the results of interview reduction. From the data is then analyzed triangulation of sources so that the conclusion of the interview results are:

1. boarding school activities are recitation and also teaching and learning activities. There are rotating picket activities for the formation of entrepreneurial characters.

2. The achievement of boarding school learning is being able to complete the Amtsilati learning method. The formation of entrepreneurial character is not a target but from pesantren facilitated through extra-curricular activities and entrepreneurial activities.

3. Learning methods used:

a. the method of conscientiousness in which Kiai figures provide good transparency, also slips materials about the independence of the mindset in every way. Also an example to plunge into the business of pesantren.

b. Habituation method is by teaching students by jumping directly into pesantren efforts to manage it. In the management of caregivers also emphasize the nature of honesty and also strengthen religious values and also goodness.

c. The method of planting discipline that is in the entrepreneurial activities of students is taught about the discipline of time, morality and discipline in the responsibility to carry out in accordance with the task given \& provide reports.

d. The method of creating a conducive atmosphere is by managing the boarding school environment conducively between business units and other business units.

e. Internalization and integration methods. Internalization by instilling the value of honesty, trust, discipline in managing it \& integration with the parachuting of students on business as a form of devotion.

4. The selection of students assigned to manage the students who have graduated from learning is chosen directly from the caregiver in terms of activeness, intelligence, ability and potential that have, have ideas, initiatives. While those assigned to help are students who still follow teaching and learning activities as a devotion of students.

5. Daily student activities in boarding schools are recitation, school, and also serving in the business

6. Caregiver instills the values of character honesty, discipline, trust, sincerity, responsible, creative and innovative.

\section{DISCUSSION}

Findings from interviews about activities and activities in pesantren can be said that Pondok Pesantren Darul Falah Amtsilati is a boarding school using the Amtsilati method which is a method of quick reading the yellow book. Character education method is basically used there are five kinds of: civility,

JMER, 2021, 02(1), 41-56 
discipline planting, habituation, creating a conducive atmosphere, as well as integrase and internalization (Falah, 2018; Hidayatullah \& Rohmadi, 2010). Basically boarding school learning can not be separated from learning, but in a boarding school there are various other activities carried out. santri feels the life of pesantren is fun, not monotonous only in the yellow book, but other activities pesantren can also unite the thoughts of various characters in an activity. In Darul Falah Amtsilati boarding school there are several learning programs. The programs of Pondok Pesantren Darul Falah Amtsilati include:

1. beginner program reads the yellow book of Amtsilati method.

2. Post-Amtsilati program and Arabic and English communication.

3. Amtsilati flash program less 3 (three) months.

4. Madrasah Ibtida'iyah Tahfidhul Qur'an.

5. Amtsilati Integrated Islamic Junior High School.

6. Madrasah Aliyah Amtsilati.

7. Extra-Curricular.

8. Practical Method Course guidance to be converted/ author of the book.

Pesantren has several programs even though the land is one. In this case the management is also petrified in organizing the activities of students. There are some extracurricular activities also provided by Darul Falah Amtsilati boarding school, where students are allowed to choose the activity according to their interests. The extra-curricular activities are tambourine, multimedia, calligraphy, art, theater, da'wah, split up, and literacy.

This pesantren business activity is one of the continuation of entrepreneurial character formation education involving all active students, namely students who still follow pesantren activities, namely recitation and learning involved in the field of entrepreneurship to help by rolling or rotating is called muawanah activities. And its management is also handed over completely to the students who have been chosen to manage it. So the selection of students is not careless, but based on the criteria required, because the students selected here will be given the task which is trusted to carry out the mandate given. Here the students do not have the ability before, therefore from the boarding school provide training and then included training. Agree with the results of the research of Rina et al., (2018) that entrepreneurial learning conducted based on the project can shape the entrepreneurial character of students. Because basically the principle of Kiai is "from santri by santri to santri" where the word "to" means to process. Processing here is interpreted as processing students with a drop in business activities in character formation, then the word "by" means to manage which is intended for students to manage it. Similarly, the results of Irawan (2019) research stated that the development of entrepreneurial independence of santri-based pesantren conducted, namely the Santri Council as the driver of the program, there is a demand to encourage the development of entrepreneurial independence of santri-based pesantren. So that it can create student independence that can be seen from the cognitive aspect, affective aspect, conative aspect, and psychomotor aspect. In accordance with the hypothesis that the formation of characters should involve students in all activities in pesantren.

Santri is also required to be able to make decisions when assigned to be the manager of one of his efforts in order to be able to know the risks and control his emotions in entrepreneurial decision making. It is agreed with Tian (2021), that personality can play a role in the training and screening of entrepreneurship. For example, risk preference is an important factor of influence, a high risk of entrepreneurship can deter some individuals who have the will and requirements to become entrepreneurs.

The achievement of boarding school learning is being able to complete the Amtsilati learning method where students can complete the yellow book. The formation of entrepreneurial character is not a target but from pesantren facilitated through extra-curricular activities and entrepreneurial activities. Entrepreneurship was initially assisted by pesantren managers. The learning element of the formation of Islamic entrepreneurial character based on the characteristics that the Prophet (pbuh) has, namely, shiddiq, amanah, fathonah, and tabligh as a reference in educating the students. So the manager is

JMER, 2021, 02(1), 41-56 
required to have methods in shaping the character of entrepreneurial students. The methods performed by pesantren are, the first, method of civility or conscientiousness. The method of conscientiousness is the same as the results of Falah (2018) research where Kiai figures provide good transparency, as well as tucking into materials about the independence of mindset in all things. Here a Kiai also set an example to plunge into pesantren business as an introduction to students are also given an understanding of entrepreneurship and modeling the Messenger of God in entrepreneurship. Here in the formation of entrepreneurial character, the child is not allowed to work by itself but also supervised while telling how to work.

Second, the habituation method, habituation is defined by the habit of doing deeds or actions consistently. As is common in boarding schools, Darul Falah Amtsilati boarding schools habituate the students with good deeds and useful morals (faedah). Especially in fostering an entrepreneurial independent character. In this case the method of habituation in boarding schools Darul Falah Amtsilati is done by teaching students by directly managing the business owned pesantren. This activity is also strengthened by giving advice, messages of kindness and honesty, as well as motivation from caregivers directly to students through learning forums and so on. The management of caregivers also emphasizes the nature of honesty and also strengthens religious values such as doing dhuha prayers first, then reading the Qur'an, listening to a 10-minute lecture and also teaching kindness. With the habituation of good things every day, these students themselves will get used to doing it. Because indirectly it has been listed in a student and has become a habit even become an obligation to do so. So that by itself the students will do things that have become his habit. Supported by the results of research (Febriyanti et al. (2018) where the formation of the character of students is carried out in nonformal education several points in the form of orientation training programs and spiritual knowledge transfer that strengthens the independence of students.

Third, the method of planting discipline. The sense of discipline itself is defined as a limitation of action but does not limit creativity to the exact same action. And according to Falah (2018), one of the methods used in character formation is by planting discipline methods to students. Here in entrepreneurial activities students are taught about the discipline of time, morality and discipline in the responsibility to carry out in accordance with the given task and give a report. With the planting of discipline in this way, it will by itself be ingrained in the students about the discipline. As well as discipline of time, then discipline in carrying out tasks, etc. It was also stated by Alma (2000) and Saepudin (2005), that discipline must be possessed by an entrepreneur.

Fourth, the method creates a conducive atmosphere. In this case to create a conducive atmosphere Pondok Pesantren Darul Falah Amtsilati do by managing and structuring the environment of boarding schools conducively between business units and other business units. By looking at the arrangement of such a conducive business location, it also facilitates students in its management. It is also puzzled by the disciplinary of time, if from the strategic arrangement and close to the cottage, automatic time used by students in carrying out their duties and carrying out their duties as students can run as it should. As is the case with research Aryani (2019), indicates that there are several conditions that shape business behavior, among others; market conditions, control of the availability of resources and environmental facilities, financial access, ability to build partners and alliances, and the role and support of the government. These environmental conditions will shape the behavior of the entrepreneur itself.

Furthermore, the Fifth method is the method of internalization and integration. Internalization by instilling the value of honesty, trust, discipline in managing it \& integration with the parachuting of students on business as a form of devotion. Where to internalize it here is done by means of caregivers providing support as well as instilling the values of character honesty, discipline, trust, sincerity, responsibility, creativity and innovation in managing it. In line with research Rina et al. (2018) and Falah (2018). The selection of students assigned to manage the students who have graduated from learning is chosen directly from the caregiver both in terms of activeness, intelligence, ability and potential, having ideas, and initiatives. While the assigned to help are the students who are still active where in this case the students who are still studying and follow the teaching and learning activities as a devotion of students. While the integration with the parachuting of students on the effort as a form of devotion without bisyaroh so that it is really from the sincerity of the heart to seek blessings. By

JMER, 2021, 02(1), 41-56 
looking at it, the students themselves feel that they are the chosen students and also given the trust to manage, so that in running they will be more careful then also do well the tasks that have been given in the field of business.

According to Falah (2018) in the process of entrepreneurial character development, the methods used are methods of civility, planting discipline, habituation, creating a conducive atmosphere, as well as integration and internalization. With this method, the process of developing the character of entrepreneurial independence of students goes well and systematically. In this study, the students who manage were given bisyaroh and should not receive pocket money. As for the boarding school Darul Falah Amtsilati santri is not given bisyaroh, but with a system of devotion to get blessings. From the formation of entrepreneurial character that is done so that students have entrepreneurial character, Darul Falah Amtsilati boarding school has included shiddiq character that is done by teaching the nature of honesty, then the mandate is done by emphasizing the sense of responsibility of the students in managing the business, further tabligh here is also taught as well as told how to manage and also convey correctly in community service, especially in the business of Amtsilati bottled water, and in the application of fathonah here from boarding schools to the selection of students who manage also based on those who have ideas, creative, innovative because it is in their management is required to work, have ideas , creative and innovative. Antonio (2011) and Jusmaliani (2014), stating economic activities require human resources that have Islamic character so that there are no irregularities in practice. For reference in managing Human Resources, namely from the Character of the Prophet. Because these qualities can also be used as a reference to foster employees to achieve the welfare of the world and the hereafter. It can also be used in the process of procurement of labor, can be used in training, can be used as a reference for management, in conclusion the character of the Messenger of Allah is an ideal attitude that must be owned by human resources of the company. Pesantren need to make a target of learning output about entrepreneurship.

Therefore pesantren is one of the non-formal educational institutions that can create prospective entrepreneurs by using the learning methods that have been described earlier so that the students can instill the attitude of shiddiq, amanah, fathonah, tabligh in entrepreneurship. With the education of entrepreneurial character, it will form new entrepreneurs in the next era. In line with the opinion of Boldureanu et al. (2020) and Sun (2020) that modern entrepreneurial education has a huge potential impact on the cultivation of more entrepreneurs in the future.

\section{CONCLUSION}

This research discusses the formation of entrepreneurial character of human resources-based students in Darul Falah Amtsilati boarding school that has several businesses and includes productive pesantren. Pesantren is one of the non-formal educational institutions based on religion that has the aim of creating human resources with karimah. On the other hand, give birth to entrepreneur people who have an Islamic entrepreneurial character.

In learning activities other than learning books, students are given learning about how to be entrepreneurial by involving them in businesses owned by pesantren. Involving students in the management of pesantren business is a facility or a way in the process of forming entrepreneurial character. Pondok Pesantren Darul Falah Amtsilati performs with several methods, namely through methods of discipleship, habituation, planting discipline, creating a conducive atmosphere, as well as integration and internalization. These methods are continuous and go hand in hand by the managers or caregivers of pesantren by emphasizing the character of the Prophet. Where the character must be owned by the students as human resources or prospective Muslim entrepreneurs by applying the attitude of shiddiq, amanah, fathonah, and tabligh. The method proved to run well in pesantren where the business unit conducted by pesantren has developed, the beginning of the business unit is only a mini market and printing, now it has been increased by the presence of building shops, Amtsilati water, Arwana café and RM Amtsilati hotel. Thus pesantren must continue to apply these methods and carry out continuous development both from the recruitment process of students to selecting cadres of business managers who have defended character learning in every learning activity teaching pesantren.

JMER, 2021, 02(1), 41-56 
The results of this study can be a recommendation for pesantren oriented to productive pesantren. The method that is felt to be more effective in shaping the character of entrepreneurship here is the method of discipleship and habituation. Because the students are very respectful of the leader of pesantren/ Kiai and in this pesantren do the bidding plunge in the business in real life. Pesantren need to make a target of learning output about entrepreneurship in accordance with the Islamic quality management system based on sharia maqasid namely the preservation of religion, life, intellectual, and descent and key success factors based on the nature of the Prophet Muhammad SAW. But in this study researchers are aware of the limitations in the study, so for further research it is better to make in-depth observations on how the management of business units managed by santri based on s human resources with system supervision and supply of entrepreneurship that has been done by pesantren caregivers so as to make pesantren productive.

\section{REFERENCES}

Al Hasan, F. A., \& Maulana, M. I. (2016). Meningkatkan Kualitas Sumber Daya Insani di Lembaga Kuangan Syariah dalam Menghadapi Persaingan Global. Social Science Education Journal, 3(1), 27-36. https://doi.org/10.15408/sd.v3i1.3795

Alma, B. (2000). Panduan Kuliah Kewirausahaan. CV Alvabeta.

Antonio, M. S. (2011). Ensiklopedia Leadership \& Manajemen Muhammad SAW "The Super Leader Super Manager (6th ed.). Tazkia Publishing.

Aryani, R. (2019). Entrepreneurship Learning Model Based on Local Wisdom for Increasing Student Creative Business. Indonesian Journal of Contemporary Education, 1(1), 24-31. https://doi.org/10.33122/ijoce.v1i1.7

Azmi, I. A. G. (2015). Islamic Human Resource Practices and Organizational Performance: Some Findings in a Developing Country. Journal of Islamic Accounting and Business Research, 6(1), 2-18. https://doi.org/10.1108/JIABR-02-2012-0010

Barnadib, I. (1987). Filsafat Pendidikan (Pengantar Mengenai Sistem dan Metode). Andi Offset.

Boldureanu, G., Ionescu, A. M., Bercu, A.-M., Bedrule-Grigoruță, M. V., \& Boldureanu, D. (2020). Entrepreneurship Education through Successful Entrepreneurial Models in Higher Education Institutions. Sustainability, 12(3), 1267. https://doi.org/10.3390/su12031267

Damihartini, R. S., \& Jahi, A. (2005). Hubungan Karakteristik Petani dengan Kompetensi Agribisnis pada Usahatani Sayuran di Kabupaten Kediri Jawa Timur. Jurnal Penyuluhan, 1(1). https://doi.org/10.25015/penyuluhan.v1i1.2097

Falah, R. Z. (2018). Membangun Karakter Kemandirian Wirausaha Santri melalui Sistem Pendidikan Pondok Pesantren. Tarbawi: Jurnal Pendidikan Islam, 15(2). 10.34001/tarbawi.v15i2.853

Fauzia, I. K., \& Riyadi, A. K. (2014). Prinsip Dasar Ekonomi Islam Perspektif. Prenada Media Group. Febriyanti, F., Affandi, I., \& Danial, E. (2018). Model Economic Development of Civics in Character Formation Plus Entrepreneurial Behavior-Based SelfReliance in the Pesantren. Advances in Social Science, Education and Humanities Research, 251, 319-323. https://www.atlantispress.com/article/25905965.pdf

Fesharaki, F., \& Sehhat, S. (2018). Islamic Human Resource Management (iHRM) Enhancing Organizational Justice and Employees' Commitment: Case of a Qard al-Hasan Bank in Iran. Journal of Islamic Marketing, 9(1), 204-218. https://doi.org/10.1108/JIMA-03-2017-0029

Hafidhuddin, D., \& Tanjung, H. (2003). Manajemen Syariah dalam Praktik. Gema Insani Press.

Halim, A., Syhartini, R., Arif, M. C., \& AS., A. S. (2005). Manajemen Pesantren. Pustaka Pesantren.

Hanani, N. (2005). Peranan Kelembagaan dalam Pengembangan Agribisnis. Pamator, 2(1).

Handayani, T. (2019). Penerapan Tradisi Keagamaan dalam Membentuk Generasi Khairu Ummah di Pondok Pesantren Sabilurrosyad Malang. Universitas Islam Negeri Maulana Malik Ibrahim.

Hasibuan, M. S. (2005). Manajemen Sumber Daya Manusia. PT. Bumi Aksara.

Hidayatullah, M. F., \& Rohmadi, M. (2010). Pendidikan Karakter: Membangun Peradaban Bangsa. Yuma Pustaka.

Indonesia Heritage Foundation (IHF). (2000a). 9 Pilar Karakter. Www.Sekolahkarakter.Sch.Id. http://sekolahkarakter.sch.id/id.php/tentang-kami/9-pilar-karakter/

Indonesia Heritage Foundation (IHF). (2000b). Sekolah Karakter Pembelajaran Holistik Membangun

JMER, 2021, 02(1), 41-56 
Karakter. Www.Sekolahkarakter.Sch.Id. http://sekolahkarakter.sch.id/id.php/tentang-kami/9pilar-karakter/

Irawan, E. (2019). Pola Pengembangan Kemandiran Kewirausahaan Pondok Pesantren Berbasis Santri. Jurnal Ekonomi Dan Bisnis Indonesia, 4(1). https://doi.org/10.37673/jebi.v4i1.284

Jusmaliani. (2014). Pengelolaan Sumber Daya Insani. PT. Bumi Aksara.

Khan, S. (2016). Islamic Perspective of Human Resource Management: Some Salient Features. Dialogue (Pakistan), 11(1), 83-106.

Koesoema, D. (2010). Pendidikan Karakter: Strategi Mendidik Anak di Zaman Global. Grasindo.

Lickona, T. (1996). Eleven Principles of Effective Character Education. Journal of Moral Education, 25(1), 93-100.

Marwansyah. (2010). Manajemen Sumber Daya Manusia. Alfabeta.

Misjaya, M., Bukhori, D. S., Husaini, A., \& Syafri, U. A. (2019). Konsep Pendidikan Kemandirian Ekonomi di Pondok Pesantren Mukmin Mandiri Sidoarjo - Jawa Timu. Edukasi Islami: Jurnal Pendidikan Islam, 8(1), 91. https://doi.org/10.30868/ei.v8i01.371

Muslich, M. (2011). Pendidikan Karakter Menjawab Tantangan Krisis Multidimensional. Bumi Aksara.

Muttaqin, R. (2016). Kemandirian dan Pemberdayaan Ekonomi Berbasis Pesantren (Studi atas Peran Pondok Pesantren Al-Ittifaq Kecamatan Rancabali Kabupaten Bandung terhadap Kemandirian Eknomi Santri dan Pemberdayaan Ekonomi Masyarakat Sekitarnya). JESI (Jurnal Ekonomi Syariah Indonesia), 1(2), 65-94. https://doi.org/10.21927/jesi.2011.1(2).65-94

Nadzir, M. (2015). Membangun Pemberdayaan Ekonomi di Pesantren. Economica: Jurnal Ekonomi Islam, 6(1), 37-56. https://doi.org/10.21580/economica.2015.6.1.785

Nasir, A. (2019). Pemberdayaan Kewirausahaan Santri Pada Pesantren Yanbu'ul Qur'an Kudus. Edukasia: Jurnal Penelitian Pendidikan Islam, 14(1), 179-204. https://doi.org/10.21043/edukasia.v14i1.3634

Nasrullah, M., Ismanto, K., \& Nalim, N. (2018). Economic Independence Of Pesantren: The Study At Pekalongan Region. HUNAFA: Jurnal Studia Islamika, 15(2), 251-272. https://doi.org/10.24239/jsi.v15i2.518.251-272

Norvadewi, N. (2018). Manajemen Sumber Daya Insani dalam Perspektif Ekonomi Islam: Tinjauan Manajemen SDM dalam Bisnis Islami. Prosiding SNMEB (Seminar Nasional Manajemen Dan Ekonomi Bisnis). https://doi.org/10.29264/prosiding\%20snmeb.v0i0.3054

Othman, K. (2017). Quality Management System vs. Maqasid Shariah Islamic Quality Management System vs. Customer Satisfaction. International Journal of Academic Research in Business and Social Sciences, 7. https://doi.org/10.6007/IJARBSS/v7-i13/3182

Priyanto, S. H. (2009). Mengembangkan Pendidikan Kewirausahaan di Masyarakat. AndragogiaJurnal PNFI, 1(1), 57-82.

Reginald, A. R., \& Mawardi, I. (2014). Kewirausahaan Sosial Pada Pondok Pesantren Sidogiri Pasuruan. Jurnal Ekonomi Syariah Teori Dan Terapan, 1(5), 333-345. https://doi.org/10.20473/vol1iss20145pp333-345

Rimbawan, Y. (2012). Pesantren dan Ekonomi: Kajian Pemberdayaan Ekonomi Pesantren Darul Falah Bendo Mungal Krian Sidoarjo Jawa Timur. Annual International Conference on Islamic Studies (AICIS) XII. https://doi.org/http://digilib.uinsby.ac.id/id/eprint/8156

Rina, L., Murtini, W., \& Indriayu, M. (2018). Organization Culture of Student Council to Shape the Students' Entrepreneurial Trait. International Conference on Teacher Training and Education (ICTTE). https://www.atlantis-press.com/article/25904886.pdf

Rivai, V. (2009). Islamic Human Capital. Rajawali Pers.

Saepudin, A. (2005). Pembelajaran Nilai-Nilai Kewirausahaan dalam Menumbuhkembangkan Kemandirian Santri (Studi Kasus Tentang Pembinaan Kemandirian Santri Melalui Program Santri Mukim Pesantren Daarut Tauhiid, Gegerkalong, Bandung). MIMBAR: Jurnal Sosial Dan Pembangunan, 21(3), 342-361. https://doi.org/10.29313/mimbar.v21i3.182

Sahlan, A. (2013). Pendidikan Karakter dalam Perspektif Islam (Kajian Penerapan Pendidikan Karakter di Lembaga Pendidikan Islam). El-Hikmah, 9(2).

Samani, M., \& Hariyanto, M. S. (2011). Konsep dan Model Pendidikan Karakter. Remaja Rosdakarya. 
Soetojo. (2013). Peningkatan Sumber Daya Manusia dan Pendidikan Kewirausahaan. Erlangga.

Subekti, M. Y. A. (2018). Pendidikan Karakter di Pondok Pesantren Anak-Anak. TaLimuna: Jurnal Pendidikan Islam, 4(1), 55-72. https://doi.org/10.32478/ta.v4i1.114

Sukirno, S., Husin, W. S., Indrianto, D., Sianturi, C., \& Saefullah, K. (2011). Pengantar Bisnis. Kencana.

Sun, D. (2020). Entrepreneurship Education Promotes Individual Entrepreneurial Intention: Does Proactive Personality Work? Open Access Library Journal, 7(10). https://doi.org/10.4236/oalib.1106835

Syafaruddin. (2012). Pendidikan dan Pemberdayaan Masyarakat. Perdana Publishing.

Syafe'i, I. (2017). Pondok Pesantren: Lembaga Pendidikan Pembentukan Karakter. Al-Tadzkiyyah: Jurnal Pendidikan Islam, 8(1), 61-82. https://doi.org/10.24042/atjpi.v8i1.2097

Syakir Sula, M., \& Kertajaya, H. (2006). Marketing Syariah. Mizan.

Syarofi, A. M. (2018). Pengembangan Jiwa Kewirausahaan Santri Melalui Ekonomi Kreatif dalam Menghadapi Tantangan Ekonomi Global (Studi di Pondok Pesantren Bahrul Maghfiroh Kota Malang). Ekonomikawan: Jurnal Ilmu Ekonomi Dan Studi Pembangunan, 17(2), 95-104. https://doi.org/10.30596/ekonomikawan.v17i2.1793

Tian, X. (2021). The Effect of Personality Traits on Entrepreneurial Development in Western China. Emerging Markets Finance and Trade, 57(5), 1284-1299. https://doi.org/10.1080/1540496X.2019.1684256

Tilaar, H. A. R. (2012). Pengembangan Kreativitas dan Enterpreneurship dalam Pendidikan Nasional. PT Kompas Media Nusantara.

Vamvaka, V., Stoforos, C., Palaskas, T., \& Botsaris, C. (2020). Attitude toward Entrepreneurship, Perceived Behavioral Control, and Entrepreneurial Intention: Dimensionality, Structural Relationships, and Gender Differences. Journal of Innovation and Entrepreneurship, 9(5). https://doi.org/10.1186/s13731-020-0112-0

Wagola, B. M. (2018). Pemberdayaan Pendidikan Kewirausahaan Di Pondok Pesantren Ulumul Quran Bojongsari Depok. Tawazun: Jurnal Pendidikan Islam, 11(1), 117-137. https://doi.org/10.32832/tawazun.v11i1.1662

\section{Appendix}

Table 1. The Results of Interview

\begin{tabular}{|c|c|c|c|}
\hline No. & Question Item & I & Result \\
\hline 1 & $\begin{array}{l}\text { What activities can shape } \\
\text { a character? }\end{array}$ & 1 & $\begin{array}{l}\text { In boarding schools there are several activities that are carried } \\
\text { out from the start of the teaching activities also KBM. While } \\
\text { in activities that can form entrepreneurial character, from the } \\
\text { cottage organizes a program whose name is muawanah } \\
\text { namely active students or recitation and KBM in the schedule } \\
\text { in turn to plunge directly into the effort to help Amtsilati } \\
\text { willingly. }\end{array}$ \\
\hline \multirow[t]{3}{*}{2} & $\begin{array}{l}\text { What are the learning } \\
\text { achievements of this } \\
\text { boarding school? }\end{array}$ & 1 & $\begin{array}{l}\text { In boarding schools there are several learning programs. So } \\
\text { the learning achievements are also different. For the } \\
\text { achievement of learning boarding school, Amtsilati itself is } \\
\text { based more on the method Amtsilati. As for the achievement } \\
\text { of entrepreneurial character formation is not a target of the } \\
\text { cottage. However, the boarding school facilitates character } \\
\text { formation, namely through some extra-curricular activities } \\
\text { provided, in accordance with which field the students want in } \\
\text { shaping their character. While in the formation of } \\
\text { entrepreneurial character of pesantren facilitated with the } \\
\text { entry santri on entrepreneurship. }\end{array}$ \\
\hline & & 2 & $\begin{array}{l}\text { Pondok Pesantren facilitates activities to shape the character/ } \\
\text { skills of students, namely through various activities } \\
\text { extracurricular also entrepreneurial. Santri just chooses which } \\
\text { one to want. }\end{array}$ \\
\hline & & 3 & Pesantren facilitate entrepreneurial activities, students choose \\
\hline
\end{tabular}




\begin{tabular}{|c|c|c|c|}
\hline No. & Question Item & $\mathrm{I}$ & Result \\
\hline \multirow[t]{9}{*}{3} & \multirow[t]{9}{*}{$\begin{array}{l}\text { What learning methods } \\
\text { are used to shape the } \\
\text { character of } \\
\text { entrepreneurship in } \\
\text { Darul Falah Amtsilati } \\
\text { students? }\end{array}$} & 1 & $\begin{array}{l}\text { their own as desired. } \\
\text { In the formation of entrepreneurial character, the child is not } \\
\text { allowed to work but also supervised and also tells how to } \\
\text { work. From there comes a lot of effort. Kiai figures also } \\
\text { provide good transparency in character formation. In learning } \\
\text { tucked material about self-reliance but not specific to } \\
\text { entrepreneurship but more on the independence of mindset } \\
\text { and so on. If in the management santi do things in accordance } \\
\text { with his duties. The management also emphasized honesty } \\
\text { because for financial problems there is no tightening in that. } \\
\text { Holding the trust system because the students are appointed to } \\
\text { manage directly in the choice by the caregiver. For the } \\
\text { arrangement of the location there is a deliberate center. And } \\
\text { it's only conducive now. }\end{array}$ \\
\hline & & 2 & $\begin{array}{l}\text { Amtsilati water efforts are carried out from its own human } \\
\text { resources where it is done by Amtsilati students themselves. } \\
\text { In addition to the introduction of santi is also given an } \\
\text { understanding of entrepreneurship and modeling the } \\
\text { Messenger of God in entrepreneurship. So that students can } \\
\text { understand or be aware of the business world. For character } \\
\text { formation every day held dhuha prayers, read the Qur'an, } \\
\text { briefing, listen to lectures } 10 \text { minutes later new production. } \\
\text { And also use the "stifin" method. Then Kiai (teacher) also } \\
\text { always controls also supervising. From the supervisor } \\
\text { continues to direct and give responsibility in accordance with } \\
\text { the task given and every day gives a report. So the formation } \\
\text { of this character is important because the character of honesty, } \\
\text { discipline is needed in business management. }\end{array}$ \\
\hline & & 3 & $\begin{array}{l}\text { Taught about the lightest part. Emphasis on the responsibility } \\
\text { of students and awareness to perform tasks. }\end{array}$ \\
\hline & & 4 & The form of learning with time, discipline, and training. \\
\hline & & 5 & $\begin{array}{l}\text { The method of learning in entrepreneurship learns by itself, } \\
\text { can be from friends and Youtube. Introduction of students } \\
\text { who still follow KBM about entrepreneurship with ta'awun } \\
\text { system (help) as a method of discipline. }\end{array}$ \\
\hline & & 6 & $\begin{array}{l}\text { There are a variety of extra-curriculars for students. Choosing } \\
\text { as desired by students by maintaining discipline and morality. }\end{array}$ \\
\hline & & 7 & Taught conscientiousness and discipline. \\
\hline & & 8 & Given training and interviews elsewhere. \\
\hline & & 9 & Study with interviews to find experiences. \\
\hline \multirow[t]{8}{*}{4} & \multirow{8}{*}{$\begin{array}{l}\text { What are the criteria for } \\
\text { students who can } \\
\text { participate in } \\
\text { entrepreneurial } \\
\text { activities? }\end{array}$} & 1 & $\begin{array}{l}\text { In the management of business the manager is chosen directly } \\
\text { by the caregiver in accordance with his criteria. However, } \\
\text { there is a muawanah program where active students are } \\
\text { assigned to assist in an effort to. }\end{array}$ \\
\hline & & 2 & $\begin{array}{l}\text { Criteria to be a business manager can be from activeness, } \\
\text { intelligence also from the length of his devotion, and also has } \\
\text { passed the Koran so that after that can be introduced with } \\
\text { entrepreneurship. }\end{array}$ \\
\hline & & 3 & $\begin{array}{l}\text { Santri who served is the santri choice of the caregiver himself. } \\
\text { Who has graduated from school so as not to interfere. }\end{array}$ \\
\hline & & 4 & $\begin{array}{l}\text { Chosen directly from the caregiver to serve with the criteria } \\
\text { and abilities that the students have. }\end{array}$ \\
\hline & & 5 & $\begin{array}{l}\text { The superiors choose students who have graduated with } \\
\text { consideration of the potential of the students. }\end{array}$ \\
\hline & & 6 & $\begin{array}{l}\text { The managing students are selected with criteria that have } \\
\text { ideas, initiatives. }\end{array}$ \\
\hline & & 7 & Who manages the students who become administrators. \\
\hline & & 8 & From the wishes of the students themselves and chosen from \\
\hline
\end{tabular}




\begin{tabular}{|c|c|c|c|}
\hline No. & Question Item & $\mathrm{I}$ & Result \\
\hline \multirow{5}{*}{5} & \multirow{5}{*}{$\begin{array}{l}\text { What are the daily } \\
\text { activities? }\end{array}$} & & their superiors. \\
\hline & & 9 & Students who can work. \\
\hline & & 4 & Already graduated, now serving in the business \\
\hline & & 5 & Serving in the business. \\
\hline & & 6 & $\begin{array}{l}\text { Reading books, teaching and learning activities, and serving in } \\
\text { the business. }\end{array}$ \\
\hline \multirow{9}{*}{6} & \multirow{9}{*}{$\begin{array}{l}\text { How is the support } \\
\text { provided by the caregiver } \\
\text { in shaping the } \\
\text { entrepreneurial character } \\
\text { of Darul Falah Amtsilati } \\
\text { students? }\end{array}$} & 7 & Reading books and serving in the business. \\
\hline & & 8 & School, reading books and serving in the business. \\
\hline & & 9 & $\begin{array}{l}\text { Not yet graduated still studying, Reading books and serving in } \\
\text { the business. }\end{array}$ \\
\hline & & 4 & $\begin{array}{l}\text { Caregivers provide support by applying honesty, discipline } \\
\text { and trust. }\end{array}$ \\
\hline & & 5 & Caregivers provide support to serve with sincerity. \\
\hline & & 6 & $\begin{array}{l}\text { Caregivers provide support as well as teach discipline by } \\
\text { teaching good manners, honesty of trust. }\end{array}$ \\
\hline & & 7 & Caregivers are supporting and emphasizing honesty. \\
\hline & & 8 & Caregivers provide support by teaching honesty and trust. \\
\hline & & 9 & $\begin{array}{l}\text { Supportive caregivers also emphasize the character of } \\
\text { responsibility, honesty, creative and innovative. }\end{array}$ \\
\hline
\end{tabular}

Source: Data processed

Note: I=Informant 